\title{
Morphological and molecular analyses of Blackfordia sp. (Hydrozoa: Leptothecata) newly discovered in Vietnam
}

\author{
Akane Iida ${ }^{1}$, Dhugal J. Lindsay ${ }^{2}$, Tran Manh Ha ${ }^{3}$, Pham The Thu ${ }^{3}$, Mitsuko Hidaka $^{2}$, \\ Sho Toshino ${ }^{4}$, Yusuke Kondo ${ }^{5}$, Susumu Ohtsuka ${ }^{5} \&$ Jun NishiKawa $^{1}$ \\ ${ }^{1}$ Graduate School of Bioscience, Tokai University, 3-20-1 Orido, Shimizu, Shizuoka, Shizuoka 424-8610, Japan \\ ${ }^{2}$ X-STAR Institute, Japan Agency for Marine-Earth Science and Technology, 2-15 Natsushima, Yokosuka, Kanagawa 237-0061, \\ Japan \\ ${ }^{3}$ Institute of Marine Environment and Resources, Vietnam Academy of Science and Technology, 246, Da Nang Street, \\ Hai Phong City, Vietnam \\ ${ }^{4}$ Kuroshio Biological Research Foundation, 560 Nishidomari, Otsuki, Hata, Kochi 788-0333, Japan \\ ${ }^{5}$ Takehara Station, Setouchi Field Science Center, Graduate School of Integrated Sciences for Life, Hiroshima University, \\ 5-8-1 Minato-machi, Takehara, Hiroshima 725-0024, Japan
}

Received 24 September 2020; Accepted 26 December 2020 Responsible Editor: Shinji Shimode

doi: $10.3800 /$ pbr. 16.118

\begin{abstract}
Hydrozoan jellyfish of the genus Blackfordia currently consist of three described species: B. manhattensis, $B$. virginica and $B$. polytentaculata. These species are distinguished by combinations of the position and shape of the gonads, the number of marginal tentacles, and the presence or absence of black pigments on the bell rim. We discovered a species of the genus Blackfordia in Vietnam for the first time. Morphological and molecular analyses revealed that this Vietnamese Blackfordia had an intermediate number of tentacles compared with its congeners, and a similar number of tentacles had been reported in Blackfordia only in Brazil, Mexico and India. Mitochondrial DNA analysis indicated that Vietnamese Blackfordia formed a sub-clade with " $B$. virginica" from Brazil, and differed from $B$. virginica from other locations, having a K2P distance of $>0.13$. These results suggest that Blackfordia sp. found in Vietnam (and Brazil) may be a different species from $B$. virginica found elsewhere, though more information is needed to establish this new species.
\end{abstract}

Key words: Blackfordia, first record, Hydrozoa, Leptomedusae, taxonomy

\section{Introduction}

Hydrozoan jellyfish of the genus Blackfordia Mayer, 1910 (Hydrozoa, Leptothecata) were first described by Mayer (1910). The genus is characterized by having four radial canals, gonads completely surrounding the radial canals, and having hollow marginal tentacles in which the endodermal cores of the tentacles extend inwards from the bell margin into the gelatinous substance of the bell (Mayer 1910, Kramp 1961). Presently, two species, Blackfordia virginica Mayer, 1910, and Blackfordia polytentaculata Hsu \& Chin, 1962 are accepted as valid, and Blackfordia manhattensis Mayer, 1910 is regarded as a synonym of $B$.

*Corresponding author: Akane Iida; E-mail, aqajakane@gmail.com virginica, based on the statements of Kramp (1958) and Moore (1987), in the World Register of Marine Species (Schuchert 2020). On the other hand, Bouillon et al. (1988) suggested that it cannot definitively be stated that $B$. manhattensis is indeed a synonym of $B$. virginica due to some ambiguity about actual morphology.

Blackfordia virginica sensu lato has been found in brackish waters from various areas from tropical to subarctic (e.g. Genzano et al. 2006, Bardi \& Marques 2009, Chícharo et al. 2009, Freire et al. 2014, Faasse \& Melchers 2014, Toyokawa \& Fujii 2015, Jaspers et al. 2018). It has attracted a large amount of scientific interest due to its known invasion history world-wide (e.g. Zaitsev \& Ōztürk 2001, Graham \& Bayha 2008). However, the area of its origin is still unclear (Mills \& Sommer 1995, Zaitsev \& Ōztürk 2001, Graham \& Bayha 2008, Leppäkoski et al. 
2009), although it appears to have been introduced from outside of the United States, presumably from the Black Sea, based on genetic analyses (Harrison et al. 2013).

In December 2017 and June 2018, 14 medusae belonging to the genus Blackfordia were discovered in Nha Trang, Vietnam, for the first time. Furthermore, one individual of Blackfordia was found in Hai Phong, the northern part of Vietnam, in July 2019. In this study, we examined the morphology and genetic composition of these Blackfordia specimens, and compared them with previously-described congeners based on morphological and molecular data.

\section{Materials and Methods}

\section{Sample collection}

A total of 15 medusae of Blackfordia were sampled in two locations in Vietnam during 2017-2019 (Table 1, Fig. 1). Fourteen were collected in the surface waters of Thuy Trieu Lagoon (Khanh Hoa) in Nha Trang $\left(12^{\circ} 04.7451^{\prime} \mathrm{N}\right.$, $109^{\circ} 10.6369^{\prime} \mathrm{E}$ ) on December 5, 2017 (4 inds.) and June 9, 2018 (10 inds.). Surface temperatures and salinities during the samplings were $27^{\circ} \mathrm{C}$ (December 2017) and $29.5^{\circ} \mathrm{C}$ (June 2018), and 25 (December 2017) and 28 (June 2018), respectively. A single individual was also collected in the Lach Huyen River mouth at Hai Phong $\left(20^{\circ} 48.1448^{\prime} \mathrm{N}\right.$, $106^{\circ} 54.5052^{\prime} \mathrm{E}$ ) on July 30,2019 (temperature $29.6^{\circ} \mathrm{C}$, salinity 10). At both locations, they were collected by performing horizontal hauls with a plankton net (diameter: $0.6 \mathrm{~m}$, mesh size: upper half, $1 \mathrm{~mm}$; lower half, $0.33 \mathrm{~mm}$ ) from a boat or a pier. Intact individuals were photographed using a digital camera, pigmentation was checked, and a few tentacles were cut off and preserved in $99.5 \%$ ethanol for molecular analyses. The remainder of each specimen was fixed in 5\% formalin-ambient seawater for morphological observations. Five individuals of Blackfordia collected in Nha Trang and Hai Phong were used only for genetic analyses because the specimens were damaged.

\section{Morphological analysis}

The morphological features of Blackfordia deemed useful for species identification in previous studies (Mayer 1910, Kramp 1961, Bardi \& Marques 2009), i.e. bell diameter, number of tentacles, the absence or presence of pigmentation between tentacles, the number of statocysts between tentacles, shape of manubrium (lips), the number of radial canals, and shape and length of gonads, were examined and compared with previous descriptions. The morphological features were observed using a stereoscopic microscope (Nikon SMZ1270). Observation was performed in both dark-field and transmitted light mode. Measurements of bell diameter were made using an ocular micrometer, corrected by an objective micrometer. Due to a lack of information, we did not correct for the possible effect of tissue shrinkage in dimension measurements using formalin-preserved gelatinous animals (Nishikawa \&
Terazaki 1996, Jaspers \& Carstensen 2009), as was also the case in other Blackfordia studies (e.g. Bardi \& Marques 2009, Harrison et al. 2013).

\section{Molecular analysis}

The tissue samples were dissolved with a $300 \mu \mathrm{L}$ of Cell Lysis Solution (Puregene Core Kit A, QIAGEN) and $5 \mu \mathrm{L}$ of $20 \mathrm{mg} \mu \mathrm{L}^{-1}$ Proteinase-K (Promega). Then, they were incubated at $37^{\circ} \mathrm{C}$ overnight or at $55^{\circ} \mathrm{C}$ for 2 hours. Protein Precipitation Solution $(100 \mu \mathrm{L})$ was added and the sample was centrifuged for 15 minutes at $15000 \mathrm{~g}$ to separate DNA from protein. $300 \mu \mathrm{L}$ of $100 \%$ propanol was added to the DNA solutions, and they were frozen at $-30^{\circ} \mathrm{C}$ for 30 minutes. Solutions were centrifuged for 15 minutes at $15000 \mathrm{~g}$ to precipitate DNA and the supernatant was removed. Then, the obtained DNA was washed with $70 \%$ ethanol, centrifuged for 15 minutes at $15000 \mathrm{~g}$ and the ethanol supernatant was removed. Total DNA was then dried, eluted with $100 \mu \mathrm{L}$ of TE-buffer, and preserved at $4^{\circ} \mathrm{C}$. Mitochondrial cytochrome oxidase $c$ subunit I (COI) and $16 \mathrm{~S}$ fragments from Blackfordia were amplified using the primers "dgLCO1490" and "dgHCO2198" for COI, and "16s. Cunningham. F. 1mod" and "16s. Cunningham. R. 2" for 16S, respectively (Harrison et al. 2013). PCR of mtDNA was carried out on a BIO RAD T100 thermal Cycler using the parameters followed in Harrison et al. (2013). PCR reaction mixture was composed of $1.5 \mu \mathrm{L}$ primer set $(10 \mathrm{mM}), 1.5 \mu \mathrm{L} 10 \times \mathrm{EX}$ buffer, $1.5 \mu \mathrm{L}$ dNTP, $0.075 \mu \mathrm{L}$ Ex Taq HS, $7.425 \mu \mathrm{L}$ distilled water (DW), and $1.5 \mu \mathrm{L}$ template DNA. The PCR products were visualized by $2 \%$ agarose gel electrophoresis with MIDORI Green Direct (NIPPON genetics Co., Ltd.). PCR products were purified using Exo-Sap IT (Affymetrix) and directly sequenced using the BigDye terminator ver. 3.1 (ABI). Cycle sequence reaction was repeated for 40 cycles of $96^{\circ} \mathrm{C}$ for 10 seconds, $50^{\circ} \mathrm{C}$ for 5 seconds, $60^{\circ} \mathrm{C}$ for 2.5 minutes. Reaction was carried out in a total volume of $11 \mu \mathrm{L}$, containing $7 \mu \mathrm{L}$ DW, $1.5 \mu \mathrm{L} 5 \times$ Sequencing buffer, $0.5 \mu \mathrm{L}$ forward primer, $1 \mu \mathrm{L}$ BigDye, and $0.5 \mu \mathrm{L}$ PCR products. Cycle sequence products were precipitated using $99.5 \%$ ethanol containing $125 \mathrm{mM}$ EDTA, and replaced with $15 \mu \mathrm{L}$ Hi-Di TM formamide (ABI). Each mtDNA sequence was checked by eye and aligned using MEGA ver.7 (Kumar et al. 2016). Haplotypes were assigned by FaBox (Villesen 2007), and haplotype networks were constructed using statistical parsimony in TCS ver.1.21 (Clement et al. 2000). The sequences of Blackfordia sp. obtained in this study were aligned with those of Blackfordia spp. in other regions reported in the National Center for Biotechnology Information (NCBI) Gene Bank (Table S1). Phylogenetic analyses (maximum-likelihood, neighbor-joining) were performed using MEGA. The most appropriate models estimated by

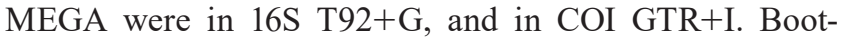
strap support values were calculated with 1000 replicates for both. Plumularia hyalina (Bale, 1882) and Nemertesia antennina (Linnaeus, 1758) were used as the outgroup for 
Table 1. Sample information for Blackfordia examined in this study. Sample numbers, sampling years and locations, morphological information, and the samples used for morphological (Morph) and molecular (Mol) examinations are shown.

\begin{tabular}{|c|c|c|c|c|c|c|c|c|c|}
\hline \multirow{2}{*}{$\begin{array}{l}\text { Sample } \\
\text { No. }\end{array}$} & \multirow{2}{*}{ Year } & \multirow{2}{*}{ Location } & \multirow{2}{*}{ Sex } & \multirow{2}{*}{$\begin{array}{l}\text { Bell diameter } \\
\qquad(\mathrm{mm})\end{array}$} & \multirow{2}{*}{$\begin{array}{l}\text { No. of } \\
\text { tentacles }\end{array}$} & \multirow{2}{*}{$\begin{array}{l}\text { No. of statocysts } \\
\text { between tentacles }\end{array}$} & \multirow{2}{*}{ Morph } & \multicolumn{2}{|c|}{ Mol } \\
\hline & & & & & & & & $16 \mathrm{~S}$ & $\mathrm{COI}$ \\
\hline 01 & 2017 & Nha Trang & Female & 11.2 & 113 & 1 (rarely 0) & $\bigcirc$ & & \\
\hline 02 & 2017 & Nha Trang & NA & NA & NA & NA & & $\bigcirc$ & $\bigcirc$ \\
\hline 03 & 2017 & Nha Trang & NA & NA & NA & NA & & $\bigcirc$ & $\bigcirc$ \\
\hline 04 & 2017 & Nha Trang & NA & NA & NA & NA & & $\bigcirc$ & $\bigcirc$ \\
\hline 05 & 2018 & Nha Trang & Female & 6.7 & 108 & 1 (rarely 0 ) & $\bigcirc$ & $\bigcirc$ & $\bigcirc$ \\
\hline 06 & 2018 & Nha Trang & Female & 9.2 & 104 & 1 (rarely 0) & 0 & $\bigcirc$ & $\bigcirc$ \\
\hline 07 & 2018 & Nha Trang & Male & NA & 112 & 1 (rarely 0) & $\bigcirc$ & $\bigcirc$ & $\bigcirc$ \\
\hline 08 & 2018 & Nha Trang & Immature & 3.8 & 48 & 1 (rarely 0 ) & $\bigcirc$ & $\bigcirc$ & $\bigcirc$ \\
\hline 09 & 2018 & Nha Trang & Immature & 4.2 & 60 & 1 (rarely 0 ) & $\bigcirc$ & $\bigcirc$ & $\bigcirc$ \\
\hline 10 & 2018 & Nha Trang & Immature & 4.5 & 48 & 1 (rarely 0 ) & $\bigcirc$ & $\bigcirc$ & $\bigcirc$ \\
\hline 11 & 2018 & Nha Trang & Immature & 4.5 & 60 & 1 (rarely 0 ) & 0 & $\bigcirc$ & $\bigcirc$ \\
\hline 12 & 2018 & Nha Trang & Immature & 3.5 & 60 & 1 (rarely 0 ) & $\bigcirc$ & $\bigcirc$ & $\bigcirc$ \\
\hline 13 & 2018 & Nha Trang & Immature & 2.8 & 52 & 1 (rarely 0$)$ & $\bigcirc$ & $\bigcirc$ & \\
\hline 14 & 2018 & Nha Trang & NA & NA & NA & NA & & $\bigcirc$ & $\bigcirc$ \\
\hline \multirow[t]{2}{*}{15} & 2019 & Hai Phong & NA & NA & NA & NA & & $\bigcirc$ & $\bigcirc$ \\
\hline & & & & & & Total & 10 & 14 & 13 \\
\hline
\end{tabular}

NA: Not available.



Fig. 1. Sampling locations of hydrozoan Blackfordia sp. in Vietnam. A, Lach Huyen River mouth, Hai Phong; B, Thuy Trieu Lagoon, Nha Trang. 


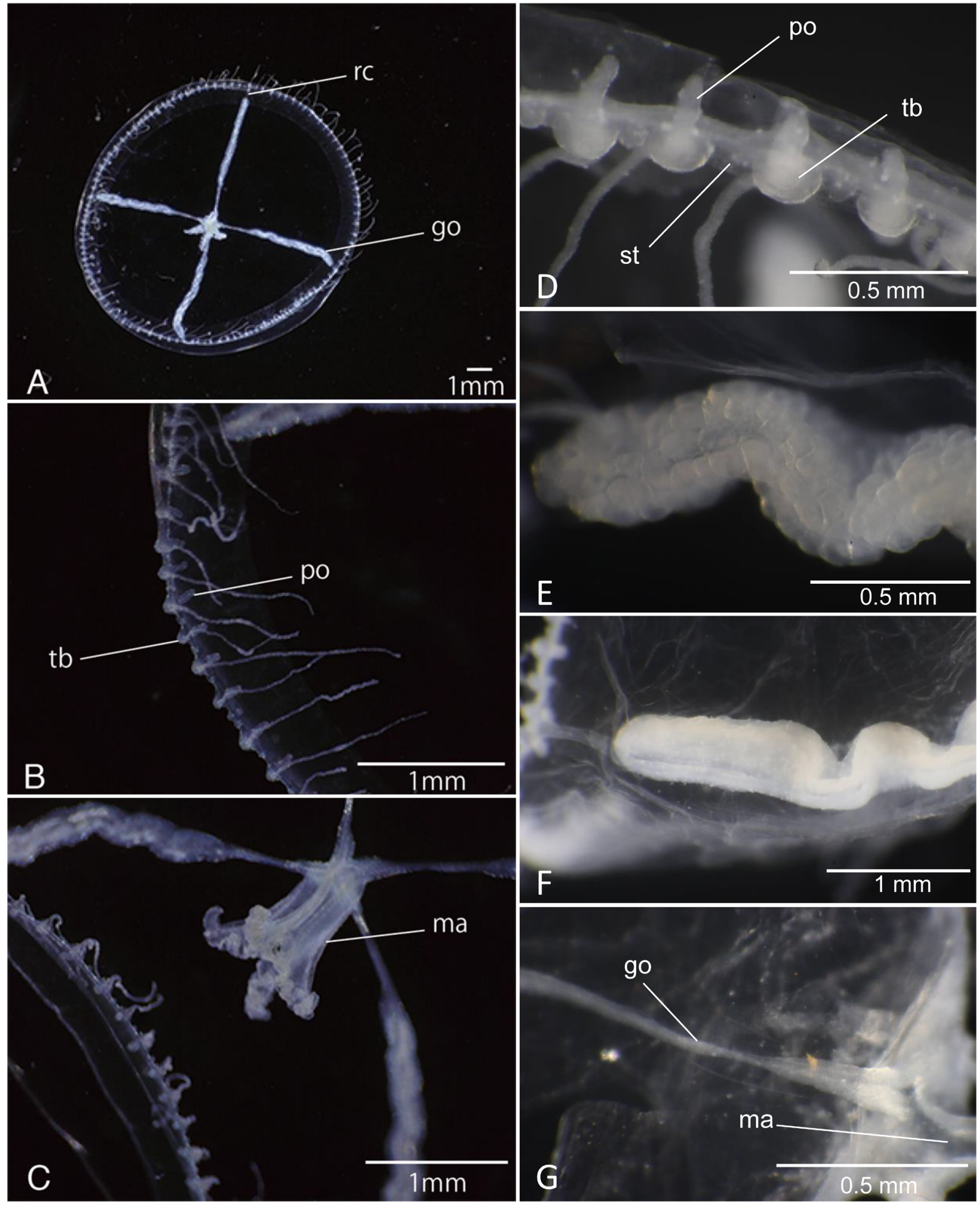

Fig. 2. Blackfordia sp. collected in Nha Trang, Vietnam. A: subumbrellar view showing radial canals (rc) and gonads (go), B: tentacular bulbs (tb) and tentacular bulb projections (po), C: manubrium (ma), D: close-up view of umbrellar margin showing tentacular bulbs (tb), tentacular bulb projections (po), and statocysts (st), E: matured gonad of female, F: matured gonad of male, G: immature gonad (go), and manubrium (ma). A-C: a female, bell diameter $11.2 \mathrm{~mm}, \mathrm{D}, \mathrm{E}$ : a female, bell diameter $6.7 \mathrm{~mm}$, F: a male, bell diameter unknown, G: an immature specimen, $4.2 \mathrm{~mm}$. 
the phylogenetic analysis. Kimura's two-parameter model (K2P, Kimura 1980) was applied to calculate the gene distances between each region using MEGA. MtDNA 16S and COI haplotypes of Blackfordia sp. obtained in this study were deposited in NCBI Gene Bank under accession numbers LC576399-LC576403 and LC576404-LC576410, respectively.

\section{Results}

\section{Morphological observations}

Of the ten individuals observed, four were mature (a male and three females) and six were immature (Table 1). Mature individuals exhibited bell diameters of 6.7$11.2 \mathrm{~mm}$ with 104-113 marginal tentacles. The bell diameters of immature individuals ranged between $2.8-4.5 \mathrm{~mm}$ with 48-60 tentacles, clearly fewer than those of adults. Both immature and mature individuals had the following features: four simple radial canals (Fig. 2A); one or rarely no statocyst present between tentacles (Table 1, Fig. 2B $\&$ D); black pigments on the marginal region were absent (Fig. 2D); manubrium with four, fluted, recurved and crenulated lips (Fig. 2C); gonads extending, along ca. 2/3 length of radial canals (Fig. 2A). In the mature individuals, the gonads were from straight to sinuous, and granulated with visible eggs in females (Fig. 2E \& F), while those of the immature individuals were linear, thin, and extending from the base of the stomach to over half or $2 / 3$ length of radial canals (Fig. 2G).

\section{Molecular analyses}

Fourteen and thirteen individuals were used for the analysis of mitochondrial $16 \mathrm{~S}$ and COI sequences, respectively (Table 1). The mitochondrial $16 \mathrm{~S}$ and COI sequences of Blackfordia sp. in two locations revealed five and seven haplotypes, respectively (Fig. 3). Haplotypes from
Hai Phong were different to those from Nha Trang. Phylogenetic analyses using both the maximum-likelihood and neighbor-joining methods showed similar patterns. The phylogenetic $16 \mathrm{~S}$ tree revealed two major clades: $B$. virginica sensu lato, including Blackfordia sp. found in Vietnam, and B. polytentaculata (Fig. 4). In the clade of $B$. virginica sensu lato, Blackfordia sp. found in Vietnam formed a sub-clade only with "B. virginica" from Brazil. In COI, as in 16S, the phylogenetic tree showed two clades: $B$. virginica sensu lato and B. polytentaculata. Blackfordia

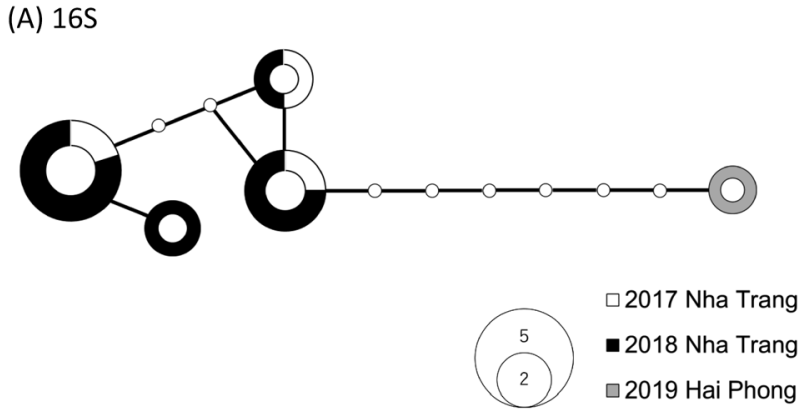

(B) $\mathrm{COI}$

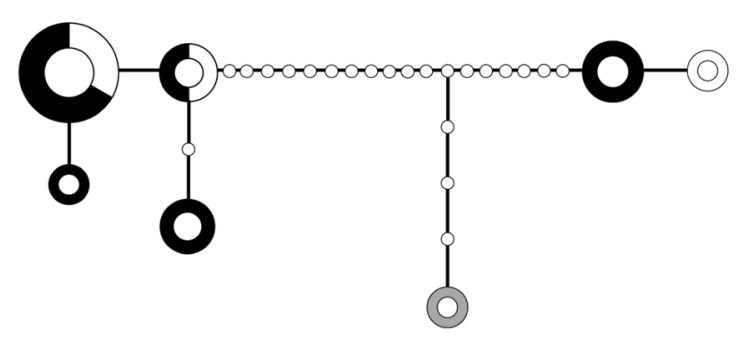

Fig. 3. Parsimony haplotype network for (A) $16 \mathrm{~S}$ and (B) COI of Blackfordia sp. in Vietnam. The size of circles is proportional to the haplotype frequency and the color of circles indicates the sampling locations and collection years. Each branch represents a one-nucleotide variation. Small empty circles symbolize hypothetical haplotypes.

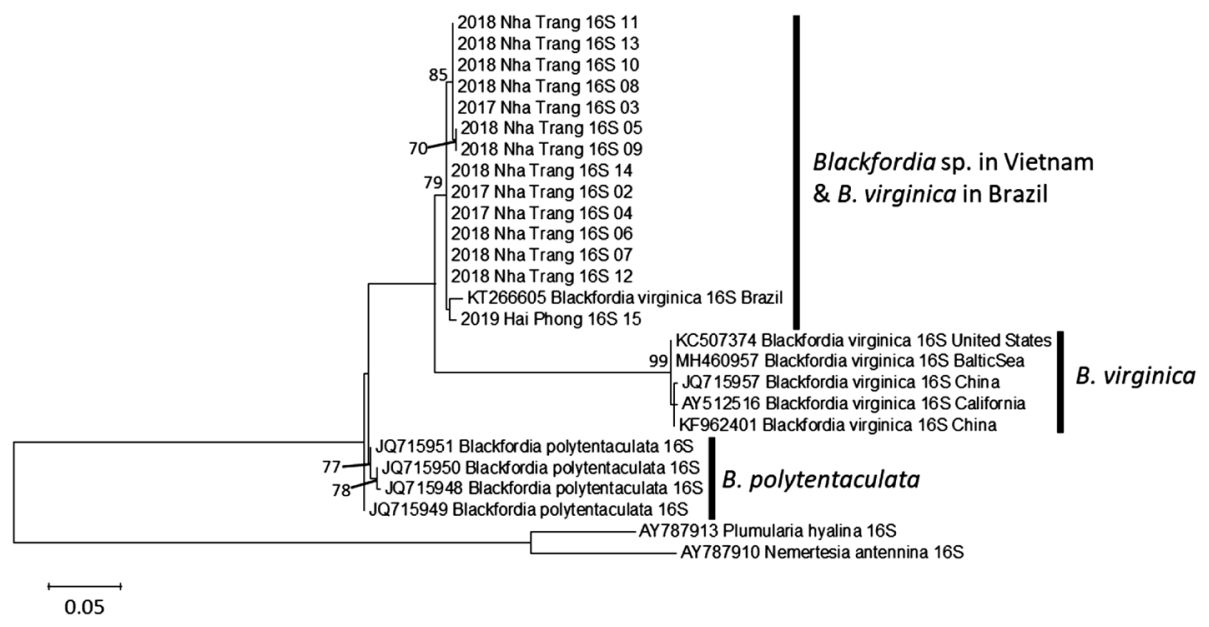

Fig. 4. Maximum likelihood tree based on mtDNA $16 \mathrm{~S}$ of Blackfordia based on our data and those of Blackfordia spp. from other regions reported in the NCBI Gene Bank (see Table S1). Bootstrap values over 70 are indicated above nodes. Number attached to each datum indicates the sample number listed in Table 1. 


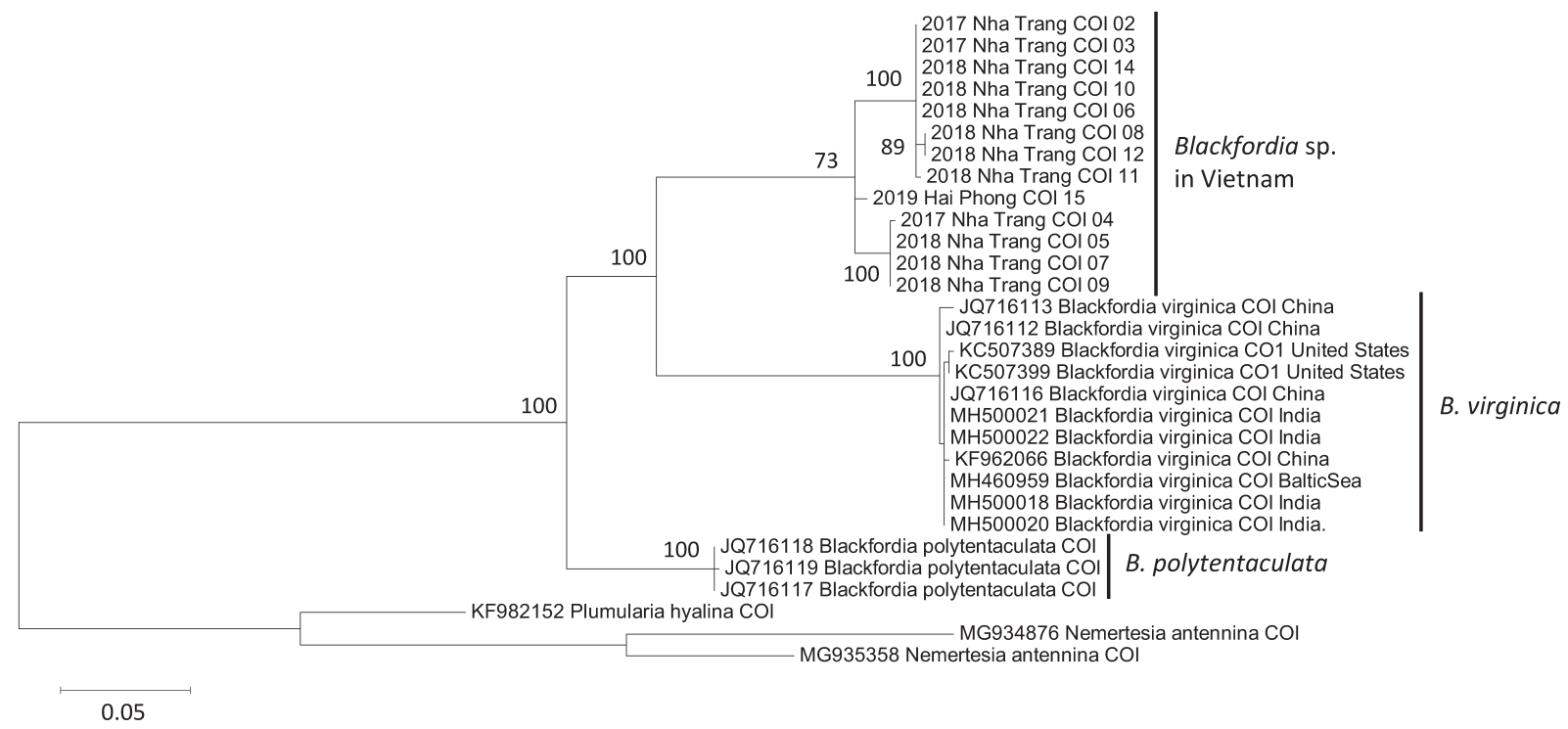

Fig. 5. Maximum likelihood tree based on mtDNA COI of Blackfordia based on our data and those of Blackfordia spp. from other regions reported in the NCBI Gene Bank (see Table S1). Bootstrap values over 70 are indicated above nodes. Number attached to each datum indicates the sample number listed in Table 1.

Table 2. Mean K2P values in $16 \mathrm{~S}$ and COI between Blackfordia sp. found in Vietnam and B. virginica in each area. Sequence data used for the countries except Vietnam were from NCBI. See Figs. 4 and 5 , and materials and methods for detailed information.

(A) $16 \mathrm{~S}$

\begin{tabular}{lllll}
\hline & Vietnam & USA $^{*}$ & China & Brazil \\
\hline Vietnam & & & & \\
USA & 0.132 & & & \\
China & 0.131 & 0.001 & & \\
Brazil & 0.015 & 0.133 & 0.132 & \\
Baltic Sea & 0.132 & 0 & 0.001 & 0.133 \\
\hline
\end{tabular}

(B) $\mathrm{COI}$

\begin{tabular}{lcccc}
\hline & Vietnam & USA $^{*}$ & China & Baltic Sea \\
\hline Vietnam & & & & \\
USA $^{*}$ & 0.135 & & & \\
China & 0.134 & 0.006 & & \\
Baltic Sea & 0.133 & 0.003 & 0.003 & \\
India & 0.134 & 0.003 & 0.003 & 0 \\
\hline
\end{tabular}

* Both Pacific and Atlantic

sp. from Vietnam was included in the former clade, and formed an independent sub-clade from $B$. virginica from other places (Fig. 5). The genetic distances (K2P) of $16 \mathrm{~S}$ between Blackfordia sp. from Vietnam and $B$. virginica in three places, i.e. the United States, China and the Baltic Sea, were relatively high $(>0.131$, Table $2 \mathrm{~A})$. In contrast, the $\mathrm{K} 2 \mathrm{P}$ between the Vietnam species and " $B$. virginica" from Brazil was much lower (0.015). For COI, the K2P between Blackfordia sp. from Vietnam and B. virginica in another four places (United States, China, the Baltic Sea, and India) were high $(>0.133$, Table $2 \mathrm{~B})$. Because the COI sequence of " $B$. virginica" from Brazil was not reported, the K2P distance between Vietnam and Brazilian specimens was unable to be calculated.

\section{Discussion}

Two species, Blackfordia manhattensis (the type species of the genus, type location: New Jersey, United States) and Blackfordia virginica (type location: Hampton Roads and Norfolk Harbor, Virginia, United States) were first described from the eastern coast of the United States (Mayer 1910). They were distinguished by the black entodermal pigment-granules adjacent to the statocysts only being present in $B$. virginica, with that species also having 1 (rarely 2) statocysts between each tentacle, in contrast to 2 (sometimes 3) in B. manhattensis, and having the linear gonads extending from the radial corners of the stomach to just over half the length of the radial canals, in contrast to sinusoidal gonads found on the middle parts of the canals in B. manhattensis (Mayer 1910). Later, a third species, Blackfordia polytentaculata was discovered based on specimens from the Fukien Coast, China (Hsu \& Chin 1962). This species is distinguishable from its congeners by the higher number of marginal tentacles (200-250) than in either B. virginica or B. manhattensis (Hsu \& Chin 1962).

Kramp $(1958,1961)$ reported that there were no black pigments in $B$. virginica sensu lato collected at the type locality of Norfolk Harbor in the United States (two specimens), Bulgaria in the Black Sea (several specimens), and India (nine specimens). Moore (1987) also reported the presence of pigment granules in only some statocysts in his specimens of $B$. virginica from the River Mira estu- 


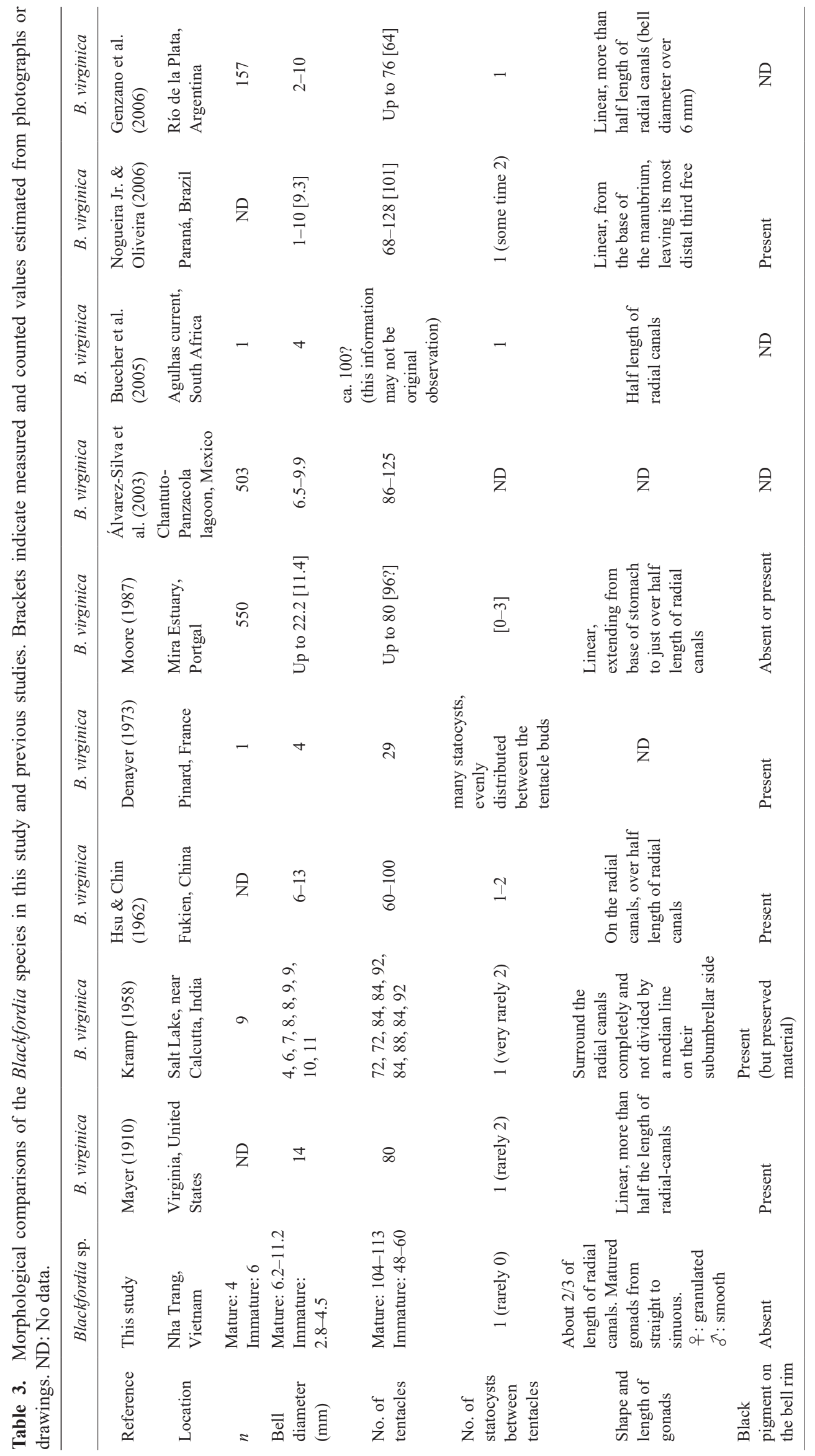




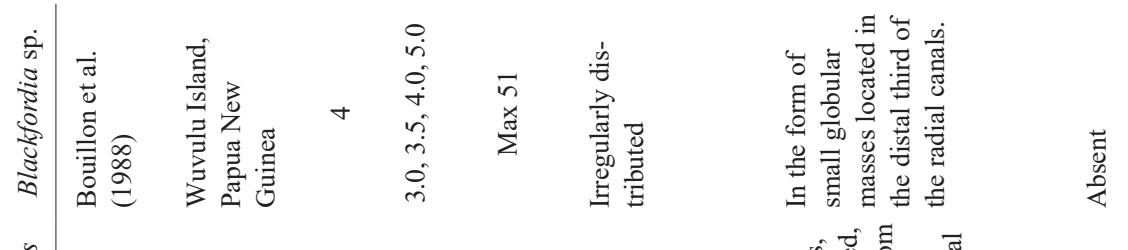



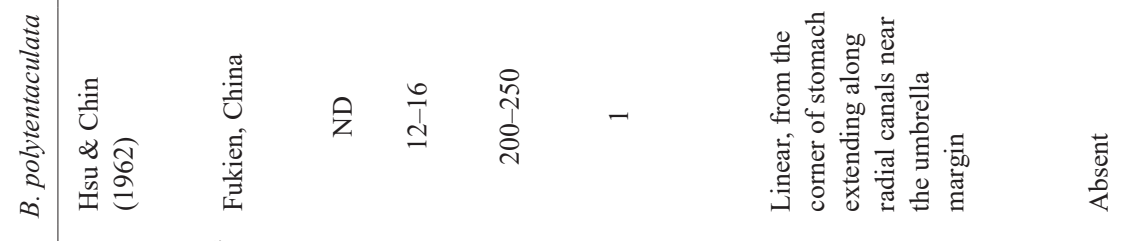

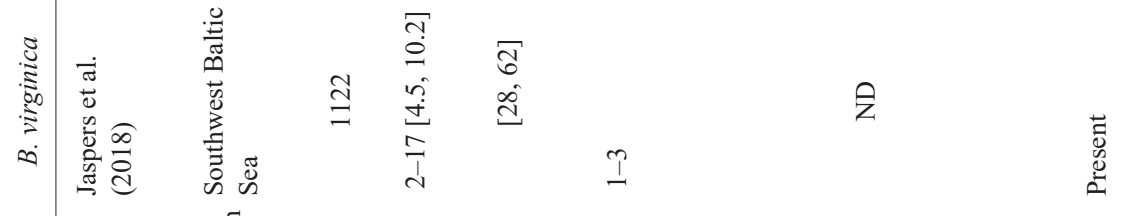

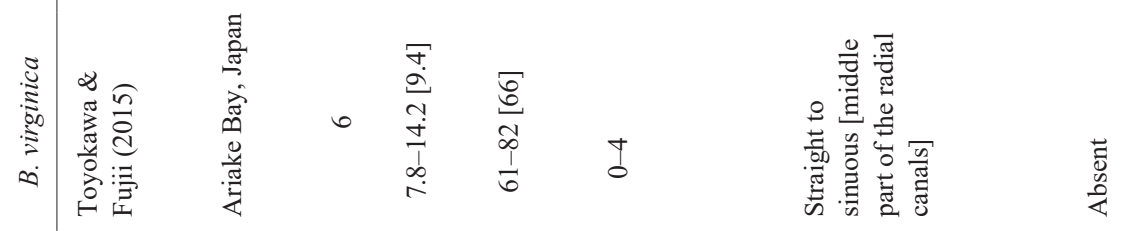

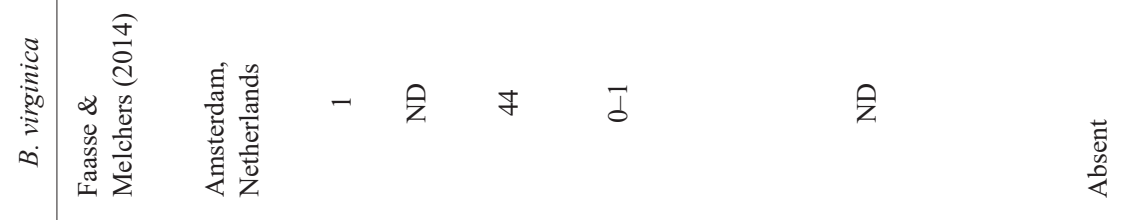

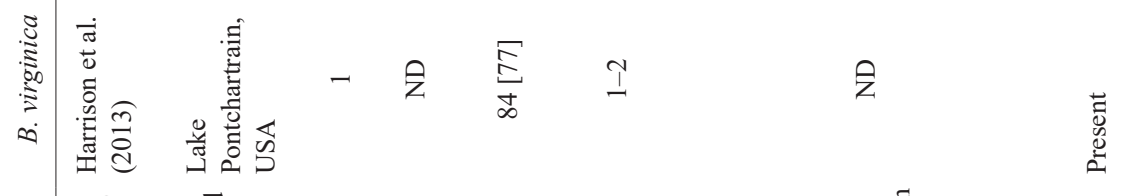





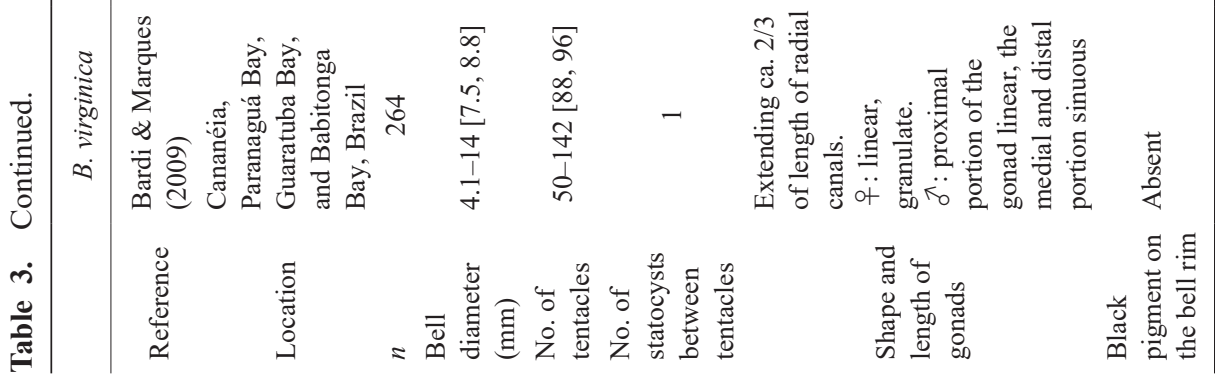


ary in Portugal, collected in 1984. Because of the presence of 1-3 intertentacular statocysts and the variable pigmentation Moore suggested that, in line with Kramp (1958, 1959), B. manhattensis is conspecific and therefore a synonym (Moore 1987). On the other hand, Bouillon et al. (1988) suggested that B. manhattensis and B. virginica should be treated as separate species until further information is available, because $\operatorname{Kramp}(1958,1959)$ and Moore (1987) both studied only fixed material in which the pigments degrade rapidly under the influence of the fixative and the continued existence of pigments can be quite random. Denayer (1973) also described that the pigment was easily degraded in fixatives. In addition, Jaspers et al. (2018) observed grey pigmentation in live individuals of $B$. virginica from the Baltic Sea. Furthermore, Bouillon et al. (1988) recorded Blackfordia sp. in Wuvulu Island, Papua New Guinea, where the species differed from other Blackfordia species, but which they did not officially describe, presumably due to the absence of mature specimens. Bardi \& Marques (2009) concluded, based on a literature survey, that the only character now useful to distinguish between the three Blackfordia species are the number of marginal tentacles. Other characters formerly used to identify the species, such as the number of statocysts between successive tentacles, gonad morphology, and the presence/ absence of black pigments have been reported as polymorphic or to be individual variations and therefore of no taxonomic significance. Presently, B. manhattensis is considered a synonym of $B$. virginica (Schuchert 2020).

At present, B. virginica + B. manhattensis and B. polytentaculata can be reliably distinguished by the number of marginal tentacles (Mayer 1910, Kramp 1961, Hsu \& Chin 1962, Bardi \& Marques 2009): B. virginica and B. manhattensis have ca. 80 tentacles and $B$. polytentaculata has 200-250. On the other hand, Bardi \& Marques (2009) reported that "B. virginica" found in Brazil had 88 and 96 tentacles (bell diameter 7.5 and $8.8 \mathrm{~mm}$, data extracted from photographs in Bardi \& Marques (2009)'s Fig. 2). While the number of tentacles was still fewer than in $B$. polytentaculata, the relationship between bell diameter and the number of tentacles is clearly that a higher number of tentacles exists for any given bell diameter than from specimens previously reported as $B$. virginica in most other studies (Table 3). The number of tentacles (48-113), including both immature and mature individuals, in Vietnamese Blackfordia was also similar to that reported for Brazilian specimens by Bardi \& Marques (2009), and showed an intermediate number between $B$. virginica and $B$. polytentaculata, in the case of mature individuals (104-113, see Table 3). Interestingly, " $B$. virginica" from Mexico and India also have been reported to have higher numbers of tentacles i.e. 86-125 (6.5-9.9 mm) (Álvarez-Silva et al. 2003) and $72(4 \mathrm{~mm})$ and $92(11 \mathrm{~mm})$ (Kramp 1958). Blackfordia virginica on the Atlantic coast of Argentina, which is relatively close to Brazil, has been reported with the number of tentacles being up to 76 (bell diameter ranged from
2-10 mm, Genzano et al. 2006), which is similar to B. virginica sensu stricto and fewer than in B. virginica sensu Bardi \& Marques, 2009 (Table 3). This evidence suggests that Blackfordia with an intermediate number of tentacles (ca. 100-140) in mature individuals have so far been found only in Vietnam (2 places), Brazil (3 places), Mexico (1 place) and India (1 place), and genetic information is available only for the former 2 locations.

Phylogenetic analyses including Blackfordia sp. from Vietnam and Blackfordia spp. in other areas revealed that the K2P distances for both 16S and COI between Blackfordia sp. in Vietnam and other locations for B. virginica were high $(>0.13)$, compared with those between Blackfordia sp. in Vietnam and " $B$. virginica" from Brazil (0.015). In Medusozoa, intraspecific and interspecific differences within genera for K2P in COI have been reported as 0.013 and 0.176 on average, respectively (Ortman et al. 2010). This suggests that the genetic differences between Blackfordia sp. and B. virginica observed in other locations, except for Brazil, were interspecific, rather than intraspecific. Currently, the K2P distances in $16 \mathrm{~S}$ in Medusoza have not been reported, with the notable exception of Lindsay et al. (2015), who reported K2P distances of 0.02 (intraspecific) and 0.18-0.23 (interspecific) for three species of the well-defined siphonophore genus Diphyes, while only a single $16 \mathrm{~S}$ sequence is provided in the NCBI Gene Bank for Brazilian B. virginica. However, a much lower genetic distance between Blackfordia $\mathrm{sp}$. and $B$. virginica sensu Bardi \& Marques, 2009, compared with other locations, implies that they might be interspecific variations.

Bardi \& Marques (2009) suggested that many morphological characters traditionally used in Blackfordia for species identification were not valid. However, their information was based on comparisons of " $B$. virginica" found in Brazil to those described in previous papers, rather than from actual $B$. virginica material from the type locality. This study showed that $B$. virginica sensu Bardi \& Marques, 2009 from Brazil may not be the same as $B$. virginica sensu Mayer, 1910, therefore their conclusion needs to be reconsidered. Some of the previous studies concerning Blackfordia contain only limited morphological information. Furthermore, the DNA analysis by Harrison et al. (2013) did not include specimens from the type location of B. manhattensis, so that the DNA sequence of B. manhattensis remains unknown and we cannot inconclusively conclude that $B$. manhattensis is a synonym of $B$. virgini$c a$. Since B. virginica and B. manhattensis are morphologically similar, it is possible that they may have been mixed up in previous reports. Therefore, as concluded by Bouillon et al. (1988), it is necessary to reconsider morphological information on Blackfordia, especially the relationship between bell diameter and tentacle number, shape, length and position of the gonads, and the number of statocysts between tentacles.

In conclusion, both morphological and genetic analyses suggest that Blackfordia sp. found in Vietnam seems to be 
a different species from B. virginica. Together with Blackfordia from Brazil, Mexico and India, they are distinguishable from congeners by the number of tentacles in adults. However, we still hesitate to establish a new species at this moment, because of the limited number of specimens, limited morphological characters unique to the species (especially those in immature stages), and limited molecular information, especially for " $B$. virginica" from Brazil, India and Mexico. Obtaining this information will clarify not only the taxonomic position of Vietnamese Blackfordia, but also enable identification of the source and the mechanism of invasion of this potentially newly-introduced jellyfish. It is the first record of Blackfordia in Vietnam, and somehow, they are similar to Blackfordia from Brazil, Mexico, and India, only. Further investigation is needed to clarify whether this jellyfish occurs in other tropical Asian areas in the future.

\section{Acknowledgements}

We thank Dr. K. Nohara, Tokai University, Japan for his assistance in molecular analysis. This study was partly supported by grants from the Japanese Society for the Promotion of Science (JSPS) KAKENHI grant number 26304030 to JN; the JSPS Core-to-Core Program CREPSUM JPJSCCB20200009; the JSPS and the Vietnamese Academy of Science and Technology under the Japan-Vietnam Joint Research Program, and the Vietnamese projects HNQT/SPĐP/15.19, QTJP01.02/19-21, ĐT.07.19/CNSHCB.

\section{References}

Álvarez-Silva C, Gómez-Aguirre S, Miranda-Arce MG (2003). Variaciones morfológicas en Blackfordia virginica (Hydroidomedusae: Blackfordiidae) en lagunas costeras de Chiapas, México. Rev Biol Trop 51: 409-412. (in Spanish with English abstract)

Bardi J, Marques AC (2009) The invasive hydromedusae Blackfordia virginica Mayer, 1910 (Cnidaria: Blackfordiidae) in southern Brazil, with comments on taxonomy and distribution of the genus Blackfordia. Zootaxa 2198: 41-50.

Bouillon J, Seghers G, Boero F, (1988) Notes additionnelles sur les méduses de Papouasie Nouvelle-Guinée (Hydrozoa, Cnidaria) III. Indo-Malayan Zool 5: 225-253. (in French)

Buecher E, Goy J, Gibbons MJ (2005) Hydromedusae of the Agulhas current. Afr Invertebr 46: 27-69.

Chícharo MA, Leitão T, Range P, Gutierrez C, Morales J, Morais P, Chícharo L (2009) Alien species in the Guadiana Estuary (SE-Portugal/SW-Spain): Blackfordia virginica (Cnidaria, Hydrozoa) and Palaemon macrodactylus (Crustacea, Decapoda): potential impacts and mitigation measures. Aquat Invasions 4: 501-506.

Clement M, Posada D, Crandall KA (2000) TCS: a computer program to estimate gene genealogies. Mol Ecol 9: 1657-1659.

Collins AG, Winkelmann S, Hadrys H, Schierwater B (2005)
Phylogeny of Capitata and Corynidae (Cnidaria, Hydrozoa) in light of mitochondrial 16S rDNA data. Zool Scr 34: 91-99.

Denayer JC, (1973) Trois méduses nouvelles ou peu connues des côtes francaises: Maeotis inexspectata Ostroomouv, 1896, Blackfordia virginica Mayer, 1910, Nemopsis bachei Agassiz, 1849. Cah Biol Mar 14: 285-294. (in French)

Faasse M, Melchers M (2014) The exotic jellyfish Blackfordia virginica introduced into the Netherlands (Cnidaria: Hydrozoa). Ned Faun Meded 43: 103-110.

Freire M, Genzano GN, Neumann-Leitão S, Pérez CD (2014) The non-indigenous medusa Blackfordia virginica (Hydrozoa, Leptothecata) in tropical Brazil: 50 years of unnoticed presence. Biol Invasions 16: 1-5.

Genzano G, Mianzan H, Acha EM, Gaitán E (2006) First record of the invasive medusa Blackfordia virginica (Hydrozoa: Leptomedusae) in the Río de la Plata estuary, Argentina-Uruguay. Rev Chil Hist Nat 79: 257-261.

Graham WM, Bayha KM (2008) Biological invasions by marine jellyfish. In: Biological Invasions vol 193 (ed Nentwig W). Springer, Berlin Heidelberg, pp. 239-255.

Harrison GF, Kim K, Collins AG (2013) Low genetic diversity of the putatively introduced, brackish water hydrozoan, Blackfordia virginica (Leptothecata: Blackfordiidae), throughout the United States, with a new record for Lake Pontchartrain, Louisiana. Proc Biol Soc Wash 126: 91-102.

Hsu C-t, Chin TG (1962) Studies on medusae from Fukien Coast. J Xiamen Univ Nat Sci 9: 206-224.

Jaspers C, Carstensen J (2009) Effect of acid Lugol solution as preservative on two representative chitineous and gelatinous zooplankton groups. Limnol Oceanogr: Methods 7: 430-435.

Jaspers C, Huwer B, Weiland-Bräuer N, Clemmesen C (2018) First record of the non-indigenous jellyfish Blackfordia virginica (Mayer, 1910) in the Baltic Sea. Helgol Mar Res 72: 1-9.

Kimura M (1980) A simple method for estimating evolutionary rates of base substitutions through comparative studies of nucleotide sequences. J Mol Evol 16: 111-120.

Kramp PL (1958) Hydromedusae in the Indian museum. Rec Indian Museum 53: 339-376.

Kramp PL (1959) The hydromedusae of the Atlantic Ocean and adjacent waters. Dana Rep 46: 1-283.

Kramp PL (1961) Synopsis of the medusae of the world. J Mar Biol Ass UK 40: 1-469.

Kumar S, Stecher G, Tamura K (2016) MEGA7: molecular evolutionary genetics analysis version 7.0 for bigger datasets. Mol Biol Evol 33: 1870-1874.

Leppäkoski E, Shiganova T, Alexandrov B (2009) European enclosed and semi-enclosed seas. In: Biological invasions in marine ecosystems (eds Rilov G, Crooks JA). Springer, Berlin Heidelberg, pp. 529-547.

Lindsay DJ, Grossmann MM, Nishikawa J, Bentlage B, Collins AG (2015) DNA barcoding of pelagic cnidarians: current status and future prospects. Bull Plankton Soc Jpn 62: 39-43.

Maronna MM, Miranda TP, Cantero ÁLP, Barbeitos MS, Marques AC (2016) Towards a phylogenetic classification of Leptothecata (Cnidaria, Hydrozoa). Sci Rep 6: 1-23.

Mayer AG (1910) Medusae of the world: volume II The Hydromedusae. In: Carnegie institution of Washington, Washington, $735 \mathrm{pp}$. 
Mills CE, Sommer F (1995) Invertebrate introductions in marine habitats: two species of hydromedusae (Cnidaria) native to the Black Sea, Maeotias inexspectata and Blackfordia virginica, invade San Francisco Bay. Mar Biol 122: 279-288.

Moore SJ (1987) Redescription of the leptomedusan Blackfordia virginica. J Mar Biol Ass UK 67: 287-291.

Nishikawa J, Terazaki M (1996) Tissue shrinkage of two gelatinous zooplankton, Thalia democratica and Dolioletta gegenbauri (Tunicata: Thaliacea) in preservative. Bull Plankton Soc Jpn 43: 1-7.

Nogueira Jr. M, Oliveira JS (2006) Moerisia inkermanica Paltschikowa-Ostroumova (Hydrozoa; Moerisiidae) e Blackfordia virginica Mayer (Hydrozoa; Blackfordiidae) na Baía de Antonina, Paraná, Brasil. Panama J Aquat Sci 1: 35-42. (in Portuguese with English abstract)

Ortman BD, Bucklin A, Pagès F, Youngbluth M (2010) DNA Barcoding the Medusozoa using mtCOI. Deep-Sea Res II 57: $2148-2156$.

Rodriguez CS (2012) Hidromedusas del Atlántico sudoccidental: Biodiversidad y patrones de distribución. PhD thesis. Mar del Plata: Universidad Nacional de Mar del Plata, pp. 92. (in Span- ish with English abstract)

Schuchert P (2014) High genetic diversity in the hydroid Plumularia setacea: a multitude of cryptic species or extensive population subdivision? Mol Phylogenet Evol 76: 1-9.

Schuchert P (2020) World Hydrozoa Database. Blackfordia Mayer, 1910. Available at: http://www.marinespecies.org/aphia. php? $=$ taxdetails\&id $=117008$ (accessed on 15 August 2020)

Toyokawa M, Fujii N (2015) First record of two invasive hydromedusae Maeotias marginata (Modeer, 1791) (Hydrozoa: Limnomedusae) and Blackfordia virginica Mayer, 1910 (Hydrozoa: Leptomedusae) in Japan. Plankton Benthos Res 10: 215-219.

Villesen P (2007) FaBox: an online toolbox for FASTA sequences. Mol Ecol Notes 7: 965-968.

Zaitsev Y, Ōztürk B (2001) Exotic species in the Aegean, Marmara, Black, Azov and Caspian Seas. Turkish Marine Research Foundation, Istanbul, Turkey, pp. 101-103.

Zheng L, He J, Lin Y, Cao W, Zhang W (2014) 16S rRNA is a better choice than COI for DNA barcoding hydrozoans in the coastal waters of China. Acta Oceanol Sin 33: 55-76. 